ESID Working Paper No.53

\title{
Political settlements, the deals environment and economic growth: The case of Ghana
}

Robert Darko Osei, ${ }^{1}$ Charles Ackah, ${ }^{2}$ George Domfe ${ }^{3}$ and Michael Danquah ${ }^{4}$

October, 2015

\footnotetext{
${ }^{1}$ Institute of Statistical Social and Economic Research (ISSER), University of Ghana, Legon, Accra.

Email correspondence: rdosei@yahoo.co.uk

${ }^{2}$ Institute of Statistical Social and Economic Research, University of Ghana, Legon, Accra.

Email correspondence: cackah@ug.edu.gh

${ }^{3}$ Centre for Social Policy Studies, University of Ghana, Legon, Accra.

Email correspondence: gdomfe@gmail.com

${ }^{4}$ Department of Economics, University of Ghana, Legon, Accra.

Email correspondence: mdanquah@ug.edu.gh

ISBN: 978-1-908749-54-3
} 


\begin{abstract}
The paper explores the extent to which political settlements, and consequently the deals environment, have influenced the growth and development outcomes for Ghana. This is done using a conceptual framework which tries to demonstrate how political settlements and the deals environment help explain sustained economic growth. Some of the key findings are summarised as follows. First, the paper notes that political settlements in Ghana have been largely personalised over the years, with electoral competition becoming a feature of the last two decades. Second, it notes that the product space for Ghana has remained largely unchanged over the years, reinforcing the argument that growth has not been structurally transformative. Third, it argues that the deals space in Ghana is largely a product of the nature of the political settlement and this in turn has contributed to growth without structural transformation of the economy. The paper concludes by noting that Ghana finds itself in a position where change to its deals space, in a way that promotes sustained accelerated growth, will be difficult.
\end{abstract}

\title{
Keywords:
}

Economic growth, political settlements, deals environment, Ghana

Osei, R. D., Ackah, C., Domfe, G. and Danquah, M. (2015). Political settlements, the deals environment and economic growth: The case of Ghana. ESID Working Paper No. 53. Manchester, UK: University of Manchester. Available at: www.effectivestates.org

This document is an output from a project funded by the UK Aid from the UK Department for International Development (DFID) for the benefit of developing countries. However, the views expressed and information contained in it are not necessarily those of, or endorsed by, DFID which can accept no responsibility for such views or information or for any reliance placed on them. 


\section{Introduction}

The typical economic growth story of Ghana starts with how for the first two-and-ahalf decades after independence, growth - and indeed the economy as a whole experienced significant fluctuations. This is then followed by the story of the structural adjustment era and the period after the country again embraced multiparty democracy. This latter period has seen more stable and improved growth (Killick, 2010). Unfortunately, this growth has not translated into significant changes in the structure of the Ghanaian economy (see Osei, 2012). Implicit in many of the writings on Ghana's growth is the fact that the political economy did play a role in shaping the growth outcomes (see Darko, 2010). It has been argued that the theory of growth cannot be adequate if it does not explain what factors are responsible for the start of a growth episode and what factors help in maintaining that growth (Pritchett and Werker, 2012). This question should be extended to Ghana, given all the discussion with respect to Ghana's growth over the years. So how do we explain the volatile nature of Ghana's growth in the first 25 years post-independence? Why did growth stabilise for another two decades? Why has the positive economic growth since the mid-1980s not translated into any significant transformation of the structure of the economy, as other writers have pointed out (see for instance Killick, 2010; Osei, 2012)? Clearly, these are important questions that will and can inform, not just policy, but the general discourse on growth episodes and how they are started and maintained.

It has been argued that the nature of political settlements in any given country has a bearing on the environment for business and that in turn affects the growth process (Sen 2012). It is also asserted that many entreprenuers in Ghana do not prioritise the expansion of their businesses (Darko, 2010: 204). In fact, a deputy Finance Minister is quoted as having stated publicly that local entrepreneurs could not be relied upon for growth and prosperity (ibid). To what extent has the nature of the political settlement and the deals environment contributed to this? What potential exists for Ghana to transition to a deals environment that supports high and sustained economic growth? This paper attempts to answer these questions, among others. In particular, it seeks to assess the role that political and institutional factors have played in shaping the deals environment and, subsequently, economic growth outcomes in Ghana.

The paper is organised as follows: in the next section we present the conceptual framework that guides the paper's analysis and discussions. This is then followed by a discussion of the different growth episodes that characterise Ghana's postindependence development. We follow that with a section discussing Ghana's growth and how it has or has not affected structural transformation. The next section discusses the evolution of Ghana's political settlements and the deals space over the post-independence period. The penultimate section discusses the deals environment in Ghana today, based on interviews with selected entrepreneurs. The final section presents the summary of findings and some concluding comments. 


\section{Conceptual framework}

In trying to understand the factors that have driven the different growth episodes in Ghana, this paper uses a conceptual framework developed by the Effective States and Inclusive Development (ESID) research centre. In this framework, the changes in GDP per capita are driven by political and economic relations that in turn drive changes in institutional and economic complexity (see Kelsall and Heng, 2014). It is argued in this framework that the type of political settlements influences elite commitment to the building of state capacity around coalitions of businesspeople and officials. These in turn affect the nature of the deals space and, consequently, medium- and long-term growth. Within this framework it is also noted that political settlements are influenced by 'rent space', which reflects the structure of opportunities in any economy. In other words, core variables, such as rent space, political settlements and state capacity, combine to influence the deals environment (institutions) and consequently impact on economic complexity (number and nature of goods and services that a country produces - the 'product space') and therefore growth and structural transformation.

As argued in Hausmann, Pritchett and Rodrik (2005), as countries move from less to more sophisticated areas of the product space, they produce goods and services that embody more knowledge and so command higher values, which translate into sustained per capita income growth. We present here brief discussions of the typologies on 'political settlements', the 'deals space', and the 'rent space'. This is done with a view to understanding how these institutional variables have influenced economic growth in a country such as Ghana.

\section{Political settlements}

One definition of political settlements is that it is "the institutional structure that creates benefits for different classes and groups in line with their relative power" (Di John and Putzel, 2009). This interdependence between the power structures and institutions in society determines the quality and performance of institutions and consequently economic growth. As Sen (2013) argues, economic institutions in a given country will reflect the choices made by society as a whole or those made by some powerful groups within it. The implicit suggestion here is that the nature of the political settlements can affect growth.

Sen (2012) identifies three channels through which politics generally can affect growth. The first is what he refers to as credible commitment by the state, or agents of the state. The argument here is that the state needs to credibly commit to potential and current investors that it will not expropriate most or all of their profits from production. In the presence of such credible commitment, entrepreneurs will commit to their investments and production. The second political channel is through the provision of public goods. Here it is noted that public goods, such as roads, electricity, education and health, are critical for long-term growth. For the state to be able to produce these public goods, it must have the capacity both to raise taxes and to administer the funds for the effective delivery of these goods. Therefore the 
dimensions of state capacity that matter here are bureaucratic and infrastructural power (Sen, 2012). The third channel is overcoming co-ordination failures. Coordination failures typically increase the costs of investments, as costs of collecting and processing information goes up for firms. This in turn reduces the incentive for entrepreneurs to invest, with adverse consequences for growth.

Sen (2012) goes on to argue that these three channels play out differently across different phases of economic growth. Institutions of credible commitment are both necessary and sufficient for growth accelerations and also contribute to growth maintenance. The provision of public goods, as well as overcoming coordination failures, are important for growth maintenance. Generally therefore it is important to locate any analysis of institutions and their evolution within the context of a political settlement typology. In other words, political settlements can help explain why the same institution can produce very good results in one country and poor results in another.

Figure 1. Types of political settlement

\begin{tabular}{|l|l|l|}
\hline & Highly personalised & Rule-governed \\
\hline Politically uncompetitive & $\begin{array}{l}\text { 1. High potential for } \\
\text { political settlements to } \\
\text { ensue }\end{array}$ & $\begin{array}{l}\text { 2. On the doorstep of } \\
\text { advanced status }\end{array}$ \\
\hline Politically competitive & $\begin{array}{l}\text { 3. Developmentally } \\
\text { challenging political } \\
\text { settlements }\end{array}$ & $\begin{array}{l}\text { 4. Most advanced country } \\
\text { political settlements }\end{array}$ \\
\hline
\end{tabular}

Source: Reproduced from Kelsall and Heng, 2014.

The political settlements typology used in this paper is based on ESID research which categorises political settlements according to how politically competitive, and how bureaucratically sophisticated a country is at any given time. It is noted that the more bureaucratically sophisticated a country is, the stronger the state capacity for sustaining economic growth. Also the more competitive the political settlement is, the shorter the length of time required by elites to create state capacity (Kelsall and Heng, 2014). Therefore the ideal political settlement for sustained economic growth is one that is politically competitive and rule-governed. In that case, the state capacity for growth maintenance can be developed rather quickly (quadrant 4 in Figure 1).

\section{Deals environment}

In the deals space we first distinguish between 'deals' and 'rules'. A pure 'rule' is completely impersonal and depends only on the state of the world and characteristics of the players that are internal to the game. A 'deal', on the other hand, is a specific action between two (or more) entities, in which the actions are not the result of the impersonal application of a rule. Rather, they are the result of characteristics or actions of specific individuals, which do not spill over with any precedential value to any other future transaction between other individuals. Pritchett and Werker (2012) note that where institutions are weak in a country, the gap between de jure policy and de facto policy as implemented tends to be large. Generally it can be argued that the de jure rules may have little relevance to the deals available to a given firm, since its 
impact on realised profitability depends on the actions that are specific to that firm. This in turn means that the deals environment is central to firms' decisions about investment, production, innovation and, consequently, sustained growth.

To explain the different possible deals environments, Pritchett and Werker (2012) suggest a two-by-two matrix where, horizontally, deals are classified as either 'closed' or 'open' and vertically they are classified as either 'disordered' or 'ordered'. Open deals are defined as deals that are widely available to all and are not confined to an elite or a small group of favoured investors. On the other hand, closed deals are those offered by the political elite to a small group of investors. In terms of the ordered versus disordered classification, these relate to whether deals are predictable and have some permanency when done. Disordered deals are unpredictable and have uncertain time dimensions, whilst the opposite is true for ordered deals. We show the different typologies in Figure 2.

Figure 2. The deals space

\begin{tabular}{|c|c|c|}
\hline & Closed deals & Open deals \\
\hline Disordered deals & $\begin{array}{l}\text { Only those with political } \\
\text { connections can make } \\
\text { deals, and even they } \\
\text { cannot be certain that } \\
\text { officials will deliver. }\end{array}$ & $\begin{array}{l}\text { Anyone can make a deal, } \\
\text { but no-one is certain that } \\
\text { officials will deliver. }\end{array}$ \\
\hline Ordered deals & $\begin{array}{l}\text { Only those with political } \\
\text { connections can make } \\
\text { deals, but they can be } \\
\text { confident that officials will } \\
\text { deliver. }\end{array}$ & $\begin{array}{l}\text { Anyone can make a deal, } \\
\text { and they can be certain } \\
\text { that officials will deliver. }\end{array}$ \\
\hline
\end{tabular}

Source: Reproduced from Sen, Kar and Sahu (2014).

Pritchett and Werker (2012) argue that an ordered but closed deals environment can sustain growth, but only for a period. For economic growth to be sustained over a longer term, such a deals environment must become more open. This is because openness in the deals space facilitates new firm entry whilst driving competition. The result is that there is an increase in the production of more complex products and a shift of resources from low productivity sectors to high productivity sectors. In other words, the growth path for any economy depends on the movements within the deals space. Through ordered deals, the state will be signalling to investors that they can commit to their investment decision and engage in production. It is important that this commitment is credible and investors should not have any doubt that the state or its agents will renege on its promise not to expropriate all or most of the rents accruing from the production process in the future (Pritchett and Werker, 2012).

The evolution of the deals space is not linear and so it is not automatic that institutions will evolve from one state to the other naturally over time. Movements in the deals space will sometimes be engendered by the nature of the structure of economic opportunities (rent space). A discussion of the different typologies associated with the rent space follows. 


\section{The nature of the rents space}

We follow the typology developed in Pritchett and Werker (2012) to discuss the four quadrants of the rent space and the corresponding demands of the state. The four categories as discussed in that paper and shown in Figure 3 are as follows.

The first is the high rent, export-orientated firms - rentiers. These typically include mining firms and agriculture firms with concessions. The firms in this quadrant are mostly foreign, as the capital outlays tend to be very high so that they typically bar most domestic firms. These firms will generally favour policies such as lower tax regimes, reduced red tape and non-intervention (Figure 3). The firms here will favour closed deals. This is because rents in these sectors have rival properties and so the more open or transparent the regulatory institutions are, the more new firms can enter the sector, and the less profits will accrue to incumbent firms.

The second quadrant is export-oriented firms that operate competitively - magicians. The firms in this quadrant favour open deals. These firms are typically very dynamic and so benefit from an open deals environment. Additionally there are a large number of economic actors in this quadrant and so the potential rents per actor tends to be low, thereby making closed deals politically not feasible.

The third category is the high rent industries that produce for the domestic market powerbrokers. The firms in this category typically form very strong relationships with the government. These firms produce for the domestic markets and are monopolistic in nature. They therefore also favour closed deals.

For the fourth quadrant we have the workhorses, which are firms that operate competitively and serve the domestic market. As with the magicians, the firms in this quadrant are many and tend to favour an open deals environment. Here also the ease of entry into the markets, plus the low rents, make them favour an open deals environment.

Pritchett and Werker (2012) argue that the types of private sector actors that are more likely to push for closed deals are firms in the rentier and powerbroker categories. This is because these firms would lose out in an open deals environment, where rents in the sectors dissipate with new firm entry or from more open and transparent regulatory institutions. Since the state plays a large role in allocating licences and controlling the entry of new firms, one would expect firms in these sectors to strike close personalised relationships with the political elite, to capture the process of licence allocation or to create artificial barriers to entry. 
Figure 3. Structure of the domestic economy, or rents space

\begin{tabular}{|c|c|c|}
\hline & High rent & Competitive \\
\hline & $\begin{array}{l}\text { RENTIERS } \\
\text { Description: Natural resource } \\
\text { exporters, agricultural concession } \\
\text { exporters. } \\
\text { Policy: Low tax regime, reduced red } \\
\text { tape, non-intervention. } \\
\text { State capability: good infrastructure } \\
\text { (can be cocooned), order, low } \\
\text { capability to regulate, negotiate, } \\
\text { enforce. }\end{array}$ & $\begin{array}{l}\text { MAGICIANS } \\
\text { Description: Manufacturing and } \\
\text { service exporters, other agricultural } \\
\text { exporters. } \\
\text { Policy: Low taxes, reduced red tape. } \\
\text { State capability: Market-friendly } \\
\text { intervention (e.g. productivity, de- } \\
\text { bottlenecking), good infrastructure (can } \\
\text { be cocooned, e.g. Special Economic } \\
\text { Zones). }\end{array}$ \\
\hline 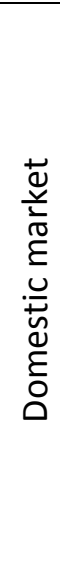 & $\begin{array}{l}\text { POWERBROKERS } \\
\text { Description: Legislative monopolies } \\
\text { or oligopolies, natural monopolies or } \\
\text { oligopolies, government services. } \\
\text { Policy: Barriers to entry, high tariffs, } \\
\text { market distortions. } \\
\text { State capability: Weak institutions, } \\
\text { lack of transparency, no bureaucratic } \\
\text { autonomy, order without rule of law. }\end{array}$ & $\begin{array}{l}\text { WORKHORSES } \\
\text { Description: Importers, traders, } \\
\text { retailers, subsistence farmers, local } \\
\text { manufacturers, producers of non- } \\
\text { tradeables. } \\
\text { Policy: Low taxes, minimal red tape, } \\
\text { good infrastructure (has to be general } \\
\text { infrastructure). } \\
\text { State capability: Need some } \\
\text { governmental capability (e.g. power, } \\
\text { roads), would prefer open order to } \\
\text { reduce costs from powerbrokers), but } \\
\text { will settle for open ordered deals. }\end{array}$ \\
\hline
\end{tabular}

Source: Adapted from Pritchett and Werker (2012).

As noted, all the categories except the powerbrokers prefer low taxes. Also, those that operate competitively prefer a strong state with limited red tape. Therefore, if the growth acceleration episode is biased towards the rentier and powerbroker sectors (say, due to a commodity price boom, or the high growth of non-tradeable sectors such as infrastructure and real estate), the economic feedback loop through the rents space could have a negative effect on the deals environment, making it more closed. On the other hand, a growth acceleration episode biased towards the magician and workhorse sectors is more likely to lead to a further opening of the deals space.

\section{Ghana's growth episodes}

Kar et al. (2013) combine a statistical and an economic-based filter to identify major trend shifts in economic growth in 125 countries over the period 1950-2010. For Ghana they find four breaks over the period covering the immediate postindependence period to date. More specifically, they identify breaks in the following years; 1966, 1974, 1983 and 2002. Apart from the 1974 break, all the identified breaks have been associated with an increase in economic growth (Figure 4). Indeed, these breaks are consistent with those that have been implicitly identified, albeit in an ad hoc way, in research on Ghana (see, inter alia, Jedwab and Osei, 2012; and Killick, 2010). As can also be noted from Figure 4, three of these breaks are related to the period when there was high volatility in the polity index and therefore political instability was high in Ghana. However, it is important to mention 
here that we do not suggest that this correlation offers a direct explanation of causation. In other words, the level of democracy alone will not be adequate in explaining these identified growth episodes. We therefore proceed to analyse Ghana's growth story using the conceptual framework discussed above and situating the discussions within these identified growth phases.

\section{Figure 4. Evolution of GDP and Ghana's growth episodes}

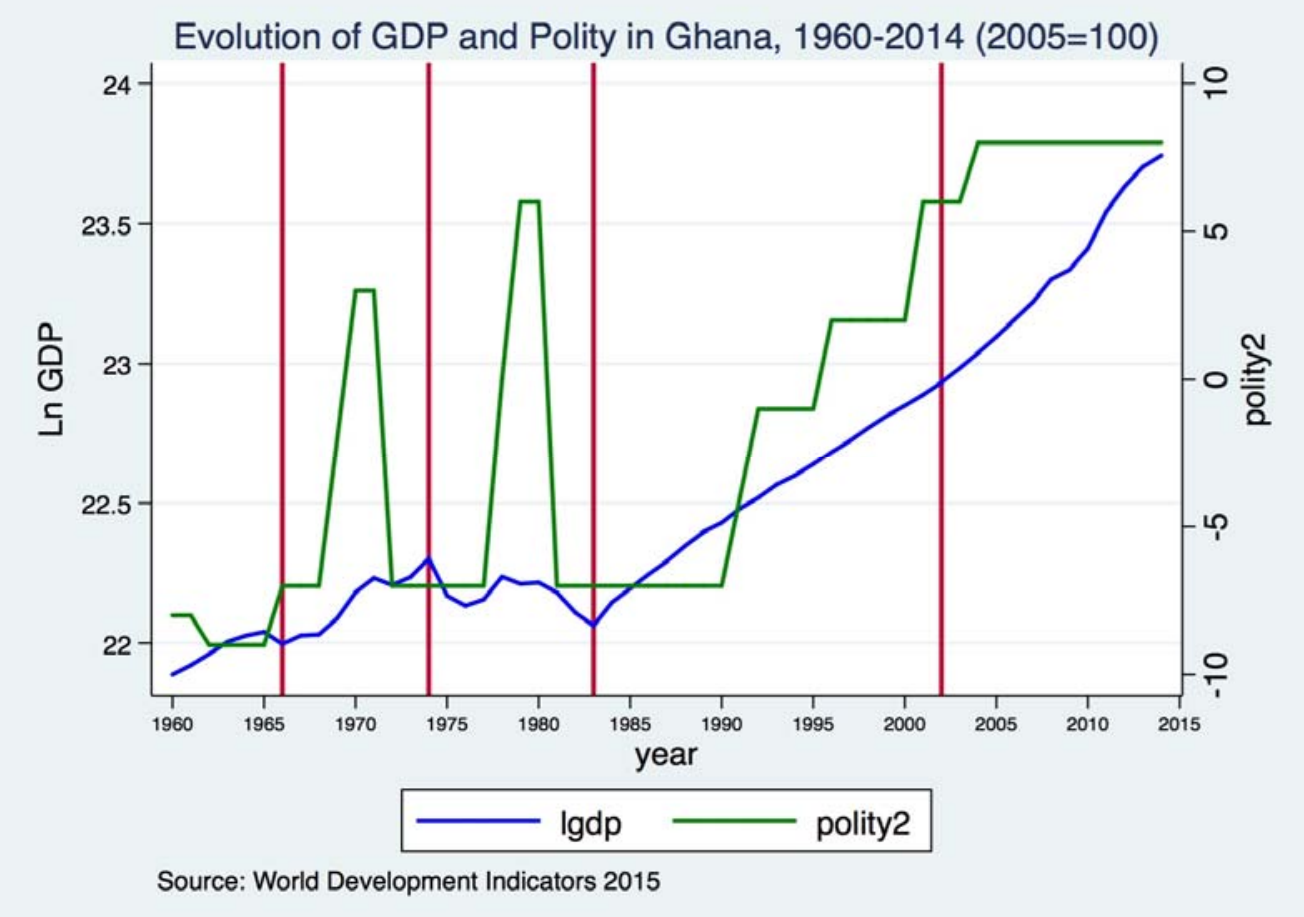

Source: World Development Indicators, 2015 and Polity IV data.

Notes: The red vertical lines reflect the periods when the breaks in growth are identified.

\section{Growth without structural transformation}

\section{Trends in economic growth}

We note from Figure 5 that between 1960 and the early part of 1980s, real GDP growth fluctuated a lot around zero. Indeed, real GDP growth over this period averaged about 1.1 percent, which translated into a negative per capita growth of -1.3 percent. This was the period of unstable political climate marked by regular government overthrow. Unsurprisingly, therefore, the real GDP did not change much, as depicted in Figure 5. From 1983 onwards, the trend did change positively, with a marked reduction in the fluctuations in real GDP growth and a positive per capita GDP - real GDP averaged about 4.3 percent over the period 1983-1999. This change in the economic fortunes of Ghana in the early 1980s has been well documented (see, inter alia, Killick, 2010; Kraev, 2004; Jedwab and Osei, 2012). In 1983 , and as part of efforts to improve the state of the Ghanaian economy, the then PNDC government adopted the World Bank's Structural Adjustment Programme (SAP). With the adoption of the SAP, the country received capital inflows, mostly from multilateral and bilateral partners (Killick and Malik, 1992). Also, as Killick (2010: 
405) notes, the immediate policy objective of the government was to restore macroeconomic stability. This entailed, among other things, bringing sanity to the exchange rate and bringing the government fiscal budget under control. A combination of these policy measures, plus increased foreign aid inflows, were significant in changing the fortunes of the country, reflected in the positive GDP growth. This continued right through to the late 1990s. The growth situation has improved further since 2000. The period from 2000 to 2012 saw an increased acceleration in the growth rate - it increased from the 1983-1999 annual average of about 4.4 percent to about 6.5 percent. The very tail end of the sample has, however, seen a slowdown in this growth, reaching under 5 percent in 2014.

Figure 5. Evolution of real GDP for Ghana, 1960-2014

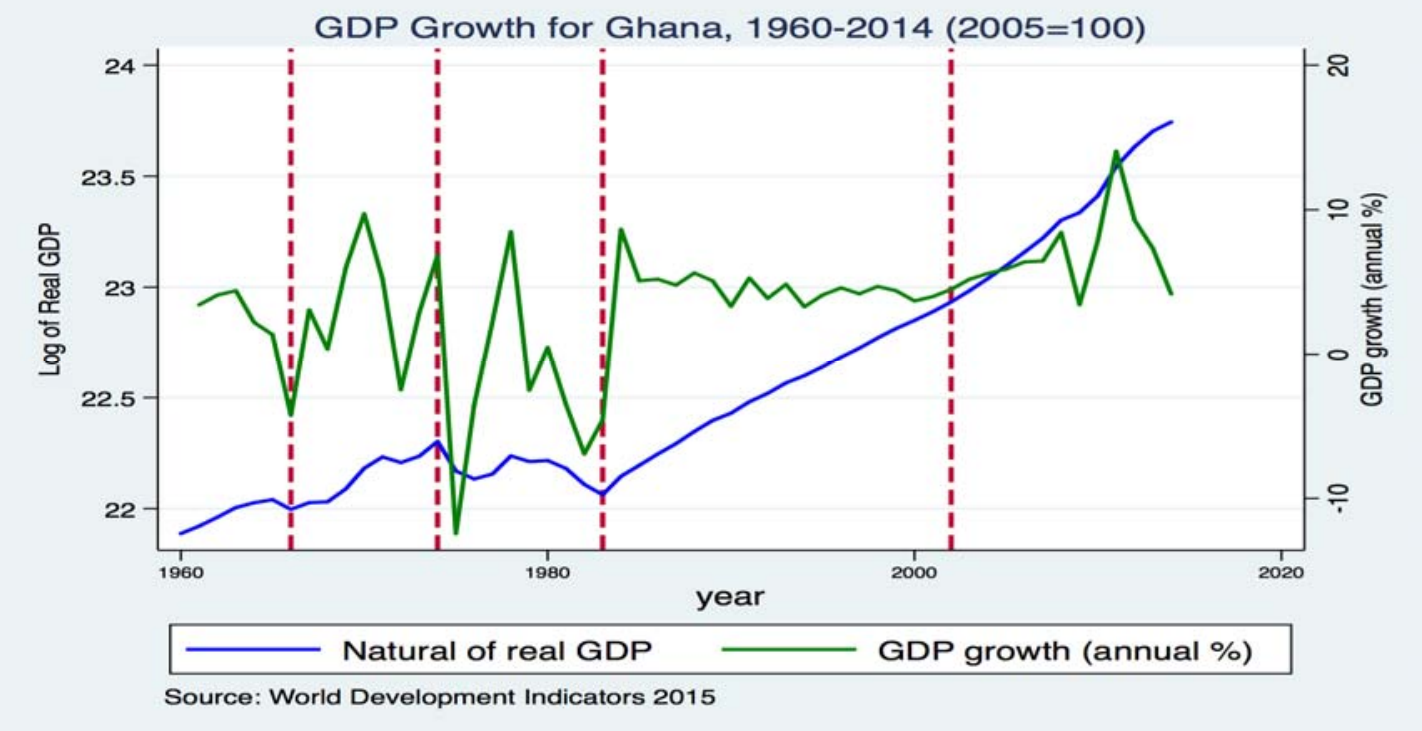

Source: World Development Indicators, 2015.

The savings and investment trends for Ghana reflect that of the GDP. We note from Figure 6 that savings and investment rates generally declined before the early 1980s. Gross domestic savings averaged about 9.9 percent of GDP. Indeed, the declining trend did not change immediately after the start of the recovery. This is not surprising, as savings will usually respond to changing economic conditions with a lag. Given the political and economic environment, it is not surprising that people had moved their savings from the country or had invested it into assets (Darko, 2010: 204). This is consistent with the argument that aid did finance public investment and therefore growth, particularly in the years of the SAP (Osei, Morrissey and Lloyd, 2005). Unfortunately, gross domestic savings still remain low, even in the 2000-2014 period, when it averaged about 8.6 percent, compared to the 9.9 percent recorded for the 1960-1982 period. We do note from Figure 6 that in 2010 the gross domestic savings rate was about the same as the 1960 s level. What this suggests is that much of the investments in the country have been financed from foreign aid and foreign private capital. 
Figure 6. Savings and investment trends for Ghana, 1960-2014 (\% of GDP)

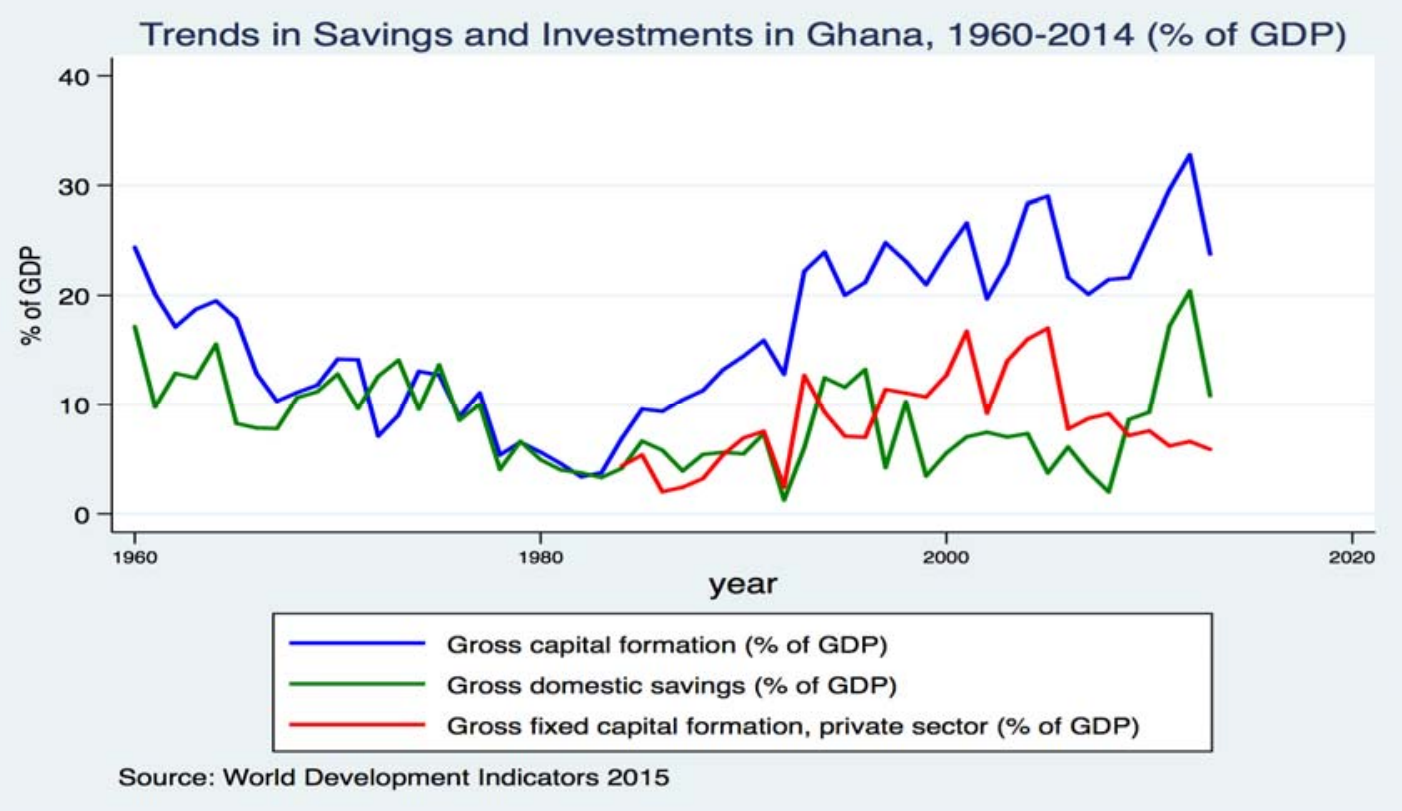

Source: World Development Indicators, 2015.

\section{Is the structure of the Ghanaian economy changing?}

We have noted that economic growth in Ghana picked up from the mid-1980s and had some features of growth maintenance. Has this been associated with a change in the structure of the economy?

Figure 7. Evolution of GDP shares in Ghana, 1960-2012

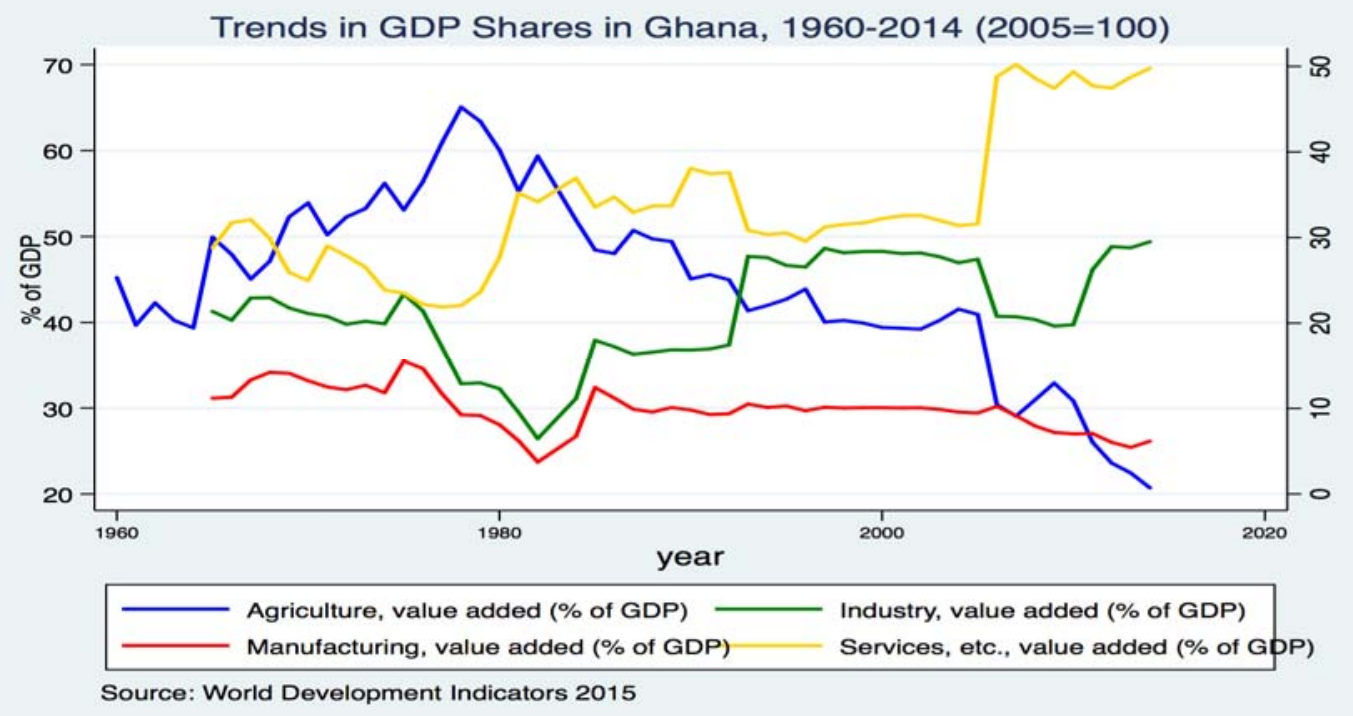

Source: World Development Indicators, 2015.

In Figure 7 we show the contribution of GDP shares for Ghana over the period 1960 to 2014. We note that agriculture remained the main contributor to Ghana's GDP until about 2006, when it was overtaken by the services sector. It is important to note that 2006 is the year that the country undertook the rebasing of the GDP, which led to an 
upward adjustment of about 75 percent. That, plus the very sharp increase between 2005 and 2006, suggests that the series may be somewhat problematic. In fact we note from Osei (2012), using data from the Ghana Statistical Service, that the services shares become more important than agriculture from about the 1990s. Importantly, two features of the trends in GDP shares are worth pointing out. First, we can argue that the services sector has become more important relative to agriculture over the years. Secondly, we note that manufacturing shares have actually declined over the years. Does this feature of the trends in GDP share reflect a changing structure of the economy?

Economic development literature will suggest that when a country is developing, there is initially a manufacturing sector boom, with the contribution of agriculture to national income declining while that of other sectors, especially manufacturing, rises. In the case of Ghana, we observe a declining agriculture sector that is associated with an increasing share of the services sector, whilst the manufacturing sector has, at best, been stagnant. This suggests that Ghana may have leapfrogged the manufacturing sector boom stage, which is typically associated with increased supply of jobs for the many who are leaving the agriculture sector. According to McMillan and Rodrik (2011), structural transformation is growth enhancing if it is associated with a shift of resources from low productivity sectors to high productivity sectors. Therefore we interrogate relevant data to assess whether the changing structure of the economy of Ghana is truly transformative.

Figure 8. Trends in employment shares for Ghana, 1991-2012

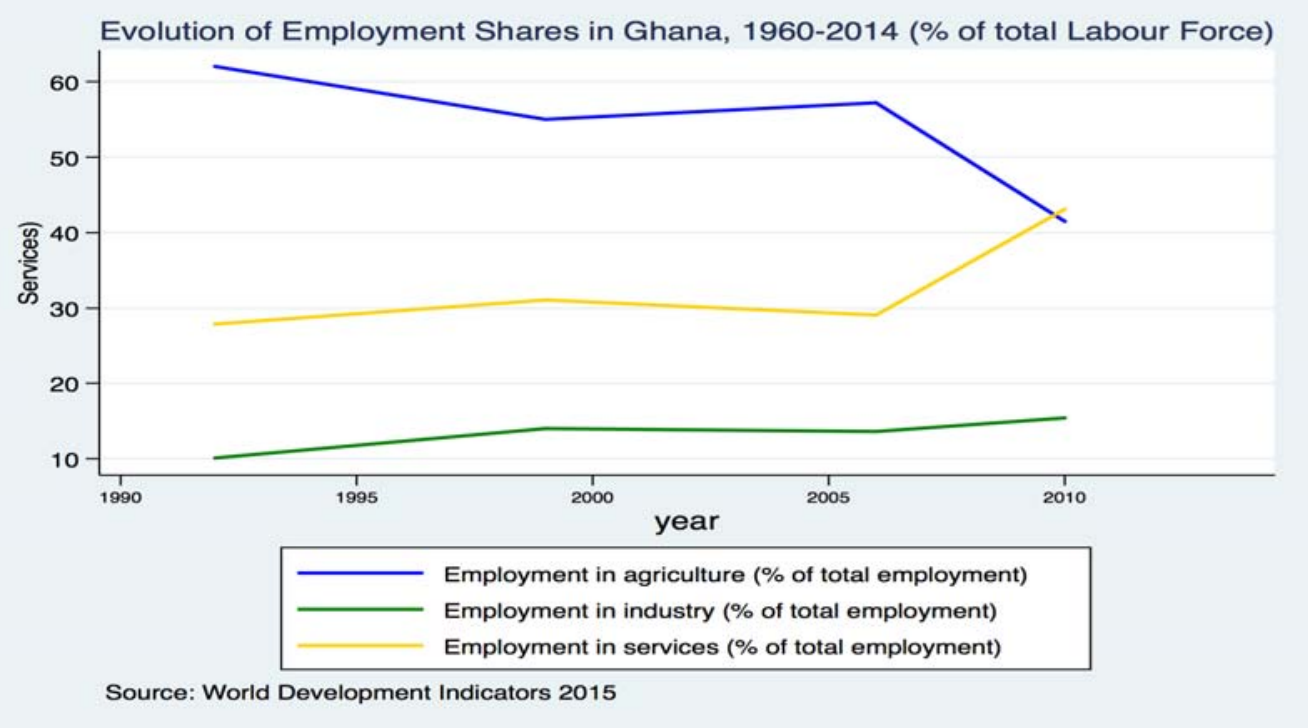

Source: World Development Indicators, 2015.

Data on employment from the World Development Indicators is limited. However, we do note from Figure 8 that in 2010 agriculture still employed about 40 percent of the labour force. This means that in spite of the fact that agriculture has in more recent times been contributing less than 30 percent of GDP, it still employs a significant proportion of the labour force. The services sector, which contributes about 50 percent of GDP, also employs almost 40 percent of the labour force. This suggests 
that agricultural productivity is lower than that of the services sector, plus the fact that labour has moved from agriculture to the services sector.

Overall, productivity in a country increases either if some sectors become more productive or when labour moves from a low productivity sector to a higher productivity one. McMillan and Rodrik (2011) describe these two channels as within and structural change channels, respectively. Jedwab and Osei (2012) argue that for Ghana the productivity in agriculture decreased until the early 1980s, then it stagnated up to the early 2000s, and started to increase from the mid-2000s. It is argued that the increase in productivity in the latter period in Ghana was a result of increasing yields in cereals and starchy roots. Indeed, part of the evolution of agricultural productivity is due to the performance of cocoa over the years. Cocoa has remained Ghana's largest export for most years, even though the sector collapsed in the 1980s.

Manufacturing exports have also remained low, owing to high wages relative to productivity (Teal, 1999) and the competition from China. The reality is that Ghana like many African countries - has urbanised without industrialisation (Gollin, Jedwab and Vollrath, 2013). For the other sub-sectors, we note that construction, typically, followed changes in economic activity with two known housing and infrastructure construction booms that occurred in the 1960s and the 2000s. The former period was in line with Nkrumah's industrialisation drive, whilst the latter coincided with a period of very high growth. The mining sub-sector having collapsed in the 1970s and 1980s, owing to persistently low investments and poor maintenance, turned around in the late 1990s, with its contribution to GDP reaching 8.5 percent in 2011, thanks to high gold prices and booming oil exports (Jedwab and Osei, 2012).

As stated above, as a country develops, the share of agriculture to GDP declines. Similarly, the share of the total population employed in agriculture also declines. Figure 8 shows that since 1991, the share of the Ghanaian population employed in agriculture steadily declined from a high of 61 percent in 1991 to around 32 percent in 2010. Also the share of the population employed in the services sector steadily rose, almost surpassing agricultural employment in 2010. The share of the population employed in manufacturing, however, remained stagnant over the years, peaking at 15 percent in 2010. Although the share of the population employed in agriculture declined, it still remains relatively important to the Ghanaian economy. Labour from the declining agriculture sector has not necessarily moved to highly productive wage employment in the services and manufacturing sectors, but rather to the equally low productivity services sector.

\section{Trend in net trade (imports versus exports)}

Trade and payment liberalisation were part of the adjustments implemented to improve Ghana's economic fortunes. The goals of the liberalisation policy were to reduce the disparity between the official and parallel exchange rates, achieve a sustainable balance of payment position, pay up debts, introduce current account 
convertibility and provide much needed foreign exchange to ease import strangulations (Aryeetey and Harrigan, 2000).

Figure 9. Trends in exports and imports for Ghana, 1960-2014

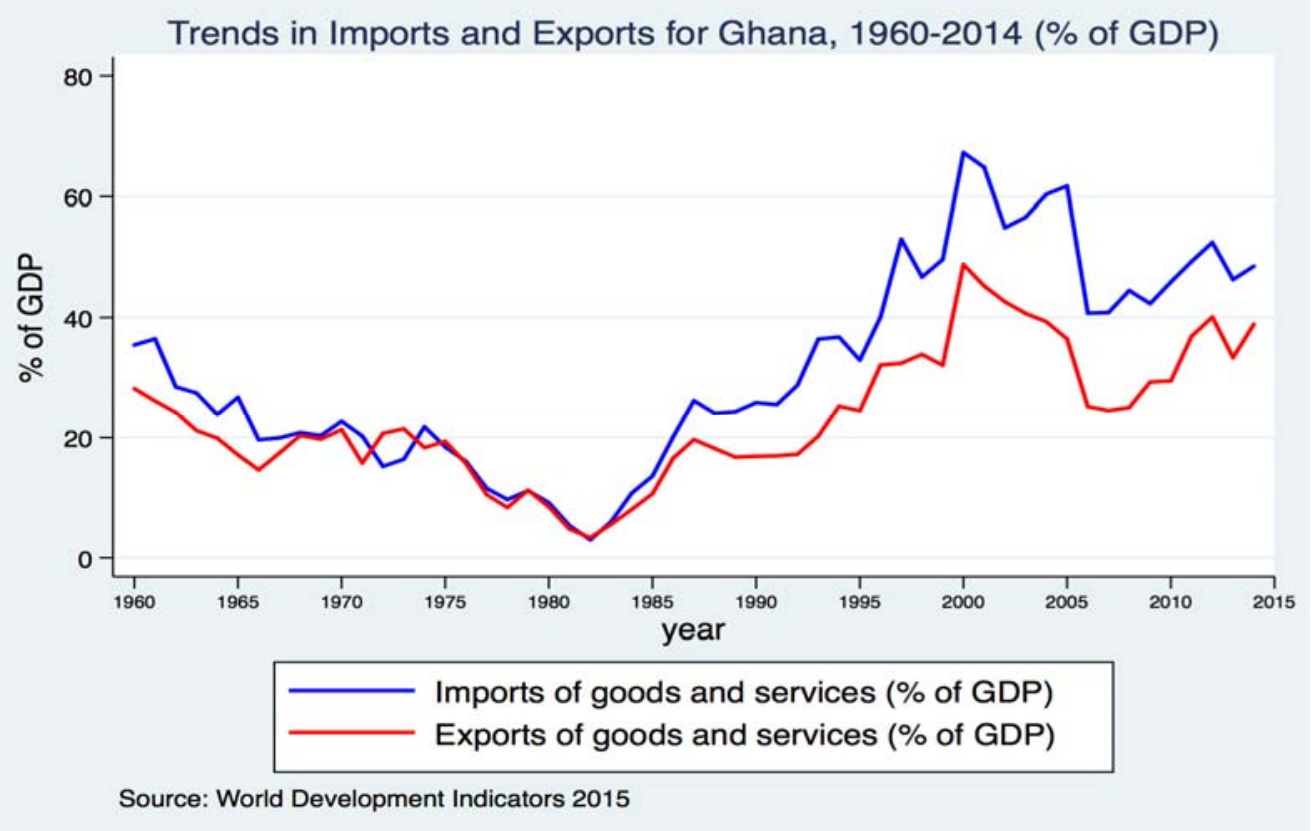

Most of these objectives were achieved, except for the sustainability of the country's balance of payment. The data indicate that both imports and exports began to rise from the mid-1980s in response to the liberalisation. While imports and exports increased at about the same rate, there was always a deficit in the trade balance because the total volume of imports always exceeded that of exports. One main reason for this is that while the population increased over the years, domestic manufacturing did not rise accordingly to make up for the shortfall in demand and the country needed to import more goods to satisfy its need. From the early 1990s, there was an emergence of rival policy objectives. According to Oduro (2000) the expansionary monetary and fiscal policies put stress on the balance of payment account. These policies put pressure on the government's budget, thereby making import liberalisation via a decreased tariff fiscally incompatible. Ghana's export-led growth has also been dominated by a small number of primary products (timber, gold and cocoa). This phenomenon makes the country's economy highly vulnerable to volatile commodity prices on the international market, compromising the sustainability of balance of payments improvements.

\section{Trends in economic complexity}

An Economic Complexity Index captures the productive structure of a given economy. It reflects the stock of knowledge that the country possesses and is measured through the composition of the output of any given country. In other words, the index captures the capabilities of the country by using the array of products that it produces (Hidalgo and Hausmann, 2009). 
Figure 10. Trends in the Economic Complexity Index for Ghana, 1960-2012

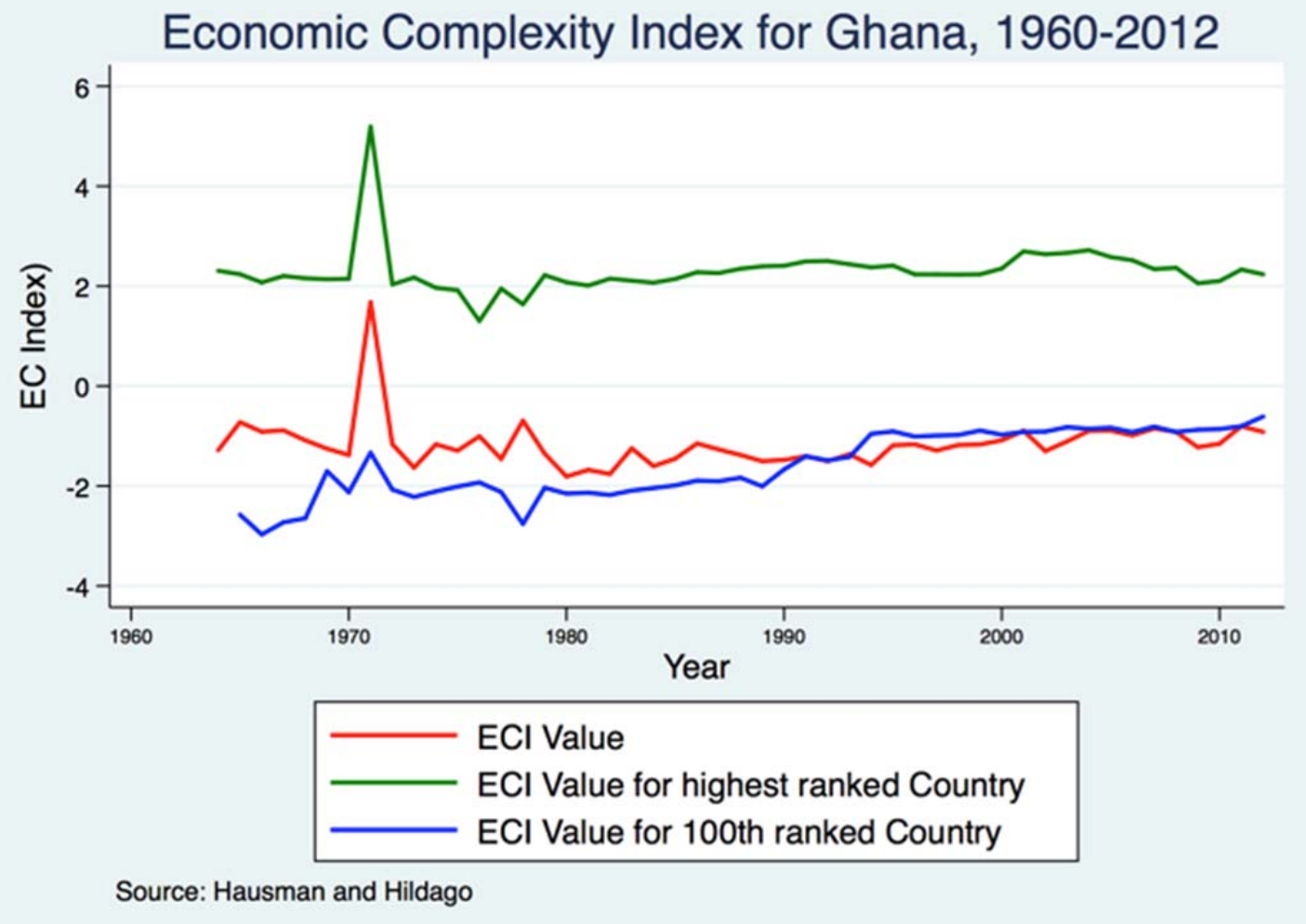

Source: Atlas of Economic Complexity, Version 1.0.7.

We plot in Figure 10 the Economic Complexity Index for Ghana, as well as that for the first and 100th ranked countries. We note that the trends for Ghana over the years support the argument made with respect to the structure of the Ghanaian economy - that the composition of GDP has changed, but the structure remains largely unchanged.

We note also for Ghana's exports (see graphs in Appendix for details) that even though the dominance of cocoa in Ghana's exports has decreased, primary products continue to dominate the export basket. For instance, we observe that the share of raw cocoa beans decreased from about 65 percent in the early 1960s to about 14 percent in 2013. Also, we now see some derivatives of cocoa - pastes and butter constituting about 4 percent, in the export basket. Of course, the start of oil production, which was about 27 percent of exports in 2013, means that all other items have had their shares reduced. In the early 1960s, over 80 percent of all the exports came from primary produce - cocoa (65 percent), crude minerals (11 percent), timber (8 percent). By 2013 the list had expanded, but was still dominated by primary exports - gold ( 25 percent), petroleum ( 27 percent), cocoa (14 percent), cocoa butter and paste (4 percent) and others. 
From the discussions in this section, we highlight three important features relating to the structure of the Ghanaian economy since the early post-independence period. First, the economic complexity index for Ghana in 2012 is not considerably different to what it was in 1960. Second, the index for the 100th ranked country (based on the 2010 economic complexity data) has caught up with Ghana in terms of productive capacity over the period. Finally, there seems to have been little convergence between Ghana and the first ranked country over the years. These trends suggest that, in spite of the changes in the composition of output in Ghana, true structural transformation, of the kind suggested by McMillan and Rodrik (2011), is yet to occur.

\section{Evolution of political settlements and the deals space in Ghana}

\section{Nature of politics and political settlements (1957-1966)}

After a few years of political agitations, the British Government granted Ghana independence on 6 March 1957. Prior to the declaration of independence, general elections were held on 17 July 1956. The Convention People's Party (CPP) of Kwame Nkrumah won 57 per cent of the total votes cast and was thus granted the mandate by the British Government to form a government (Nohlen, Thibaut and Krenn, 1999). While CPP described itself as socialist, the main opposition, United Party (UP), was pro-capitalist. The pre-independent agitations therefore gave way to an internal ideological wrangling between CPP and UP. It has been argued that quite apart from making sure capitalism did not thrive in Ghana, one of Nkrumah's top foreign priorities was to work against capitalist interests on the continent of Africa (McLaughlin and Owusu-Ansah, 1994).

Nkrumah became very powerful in Ghana, especially after successfully using constitutional process to pass the Deportation Act of 1957. While the Act empowered the Prime Minister to expel persons whose presence in the country was deemed not to be in the interest of the general public, there were situations where it was applied to persons who claimed to be Ghanaians. A year after the passage of the Deportation Act, the Preventive Detention Act, was passed to give power to the Prime Minister to detain certain persons for up to five years without trial (McLaughlin and Owusu-Ansah, 1994). Even though this Act also followed constitutional processes, the opposition described it as a deliberate restriction on political and economic freedom in Ghana. However wrong they might have been with this assertion, by 1961 an estimated 400 to 2,000 members of the opposition had been detained (ibid).

Nkrumah's rigid hold over the nation's systems became a matter of concern, especially to the members of the opposition, whose fundamental human rights were being trampled upon with impunity. The country became a republic on 1 July 1960, with Nkrumah emerging victorious in the presidential elections. Shortly after this, Nkrumah nearly gained absolute political powers when he proclaimed himself as a life president and his party, the sole party of the state. After successfully sending the opposition political parties into oblivion, Nkrumah obtained a constitutional amendment in 1964 to allow him to dismiss any judge from the bench. In spite of all 
these powers, barely a year after being re-elected as president, a police-military junta overthrew the CPP government in a military coup on 24 February 1966, while Nkrumah was away in China.

This shows that Nkrumah entrenched his political powers, sometimes via constitutional approaches, while eliminating checks and balances. He succeeded in making the judiciary, the media, the clergy, and the traditional chiefs dance to the tune of his political whims. Indeed, it has been argued that his charisma transcended the boundaries of Ghana, setting a very high international profile for himself and the country (Boafo-Arthur, 2000). Within Ghana he was the fulcrum around which everything happened. Apart from silencing his political opponents, he arrogated himself traditional powers to appoint and also abdicate traditional chiefs who openly opposed his leadership. He became the sole powerbroker after constitutionally declaring himself the life president and the CPP the sole party of the state. Most of his political opponents had to flee the country and the few who stayed and challenged him, were found guilty under the Preventive Detention Act. We would therefore argue that political settlements in Ghana over this period were personalised but competitive (at least in the initial part of the period).

\section{The deals environment (1957-1966)}

Over the 1957- 1966 period, we would argue that the deals environment was closed and ordered. From the discussion above we note that this period fell under a regime that subscribed to a central planning approach. As part of the central planning process, legislative controls were imposed on imports, capital transfers, licensing of industry, minimum wages, the rights and powers of trade unions, prices, rents and interests rates (Killick, 2010: 56-60). These, among other institutional arrangements, operated in a political space that was increasingly becoming uncompetitive and highly personalised. This unfortunately encouraged and entrenched a deals space that was closed but ordered for the formal sector. For the informal sector we argue that the deals space was open but disordered and was therefore limited in scope in terms of opportunities to expand.

\section{Nature of politics and political settlements (1966-1983)}

The National Liberation Council (NLC), consisting of four army officers and four police officers, quickly assumed executive powers of Ghana after toppling Nkrumah's government. The leadership of the coup justified their takeover by claiming that the CPP administration was abusive and corrupt (McLaughlin and Owusu-Ansah, 1994). Their main preoccupation therefore was to restore order to the inherited chaotic and abusive political system. They appointed a cabinet of civil servants and promised to restore democratic government as soon as possible. Political parties were allowed to operate by the end of 1968 . This was followed by general elections in 1969, the first competitive nationwide political contest since 1956. The major contenders were the Progress Party (PP), headed by Kofi Abrefa Busia, and the National Alliance of Liberals (NAL), led by Komla A. Gbedemah (Miller, Vandome and McBrewster, 2009). 
The pro-capitalist civilian government, Progress Party (PP), which won the elections and took over from the NLC, concerned itself more with development. At that time, the main problems facing the country were the imbalance in foreign payments, high inflationary pressures and rising unemployment rates. However, since most members of Busia's administration were considered intellectuals, the general expectations were that they would be more perceptive in their evaluations of what needed to be done (Miller et al., 2009). Busia's government initiated two policy measures soon after assuming office. These were the expulsion of large numbers of non-citizens from the country and an accompanying measure to limit foreign involvement in small businesses. While Busia became popular among the local business entrepreneurs for the introduction of these two measures, ${ }^{1}$ he was never forgiven for his decision to devalue the national currency.

Upon recommendation from the International Monetary Fund (IMF), Busia introduced austerity measures, including wage freezes and tax increases. These measures severely affected the middle class and the salaried workforce, which eventually precipitated protests from the Trade Union Congress (Miller et al., 2009). Aware that the economic austerity measures had also generated some dissatisfaction among the military officers, Busia's government quickly began to change the leadership of the army, to guard against any military upheavals. He was, however, a little too late; Lieutenant Colonel Ignatius Kutu Acheampong had already assembled his men to stage a bloodless coup on 13 January 1972 to end the Second Republic (ibid).

The coup leaders, who justified their takeover by levelling charges of corruption against Busia and his associates, formed the National Redemption Council (NRC) (Miller et. al, 2009). The NRC was a military government and never outlined any plan for the return of the nation to democracy in its early years (McLaughlin and OwusuAnsah, 1994). In an attempt to correct the wrongs of the previous administration, Busia's economic austerity measures were reversed. For example, Acheampong revalued the Ghanaian currency upwards and unilaterally rescheduled Ghana's foreign debt. A large number of foreign-owned companies were also nationalised (ibid).

Acheampong's aim of utilising local capacity to build an independent economy was overridden by oil price hikes in 1974, a decline in cocoa output, drought and the lack of foreign exchange. Disillusionment with the government developed and allegations of corruption, favouritism and incompetence in the management of the economy were levelled against Acheampong and his associates. According to Taylor (1988), this gross economic mismanagement led to an exchange rate that was almost 1,000 percent overvalued. Unavailability of foreign exchange and credit led to closure of some giant domestic industries, as many were unable to operate, due to lack of parts and intermediate inputs (Kraev, 2004).

\footnotetext{
${ }^{1}$ The policies forced foreigners out of the retail sector of the economy, especially Lebanese, Asians and Nigerians, who were perceived as unfairly monopolising trade to the disadvantage of Ghanaians.
} 
In the midst of these developments, the NRC was reorganised into the Supreme Military Council (SMC) in 1975 (McLaughlin and Owusu-Ansah, 1994). A few civilians were appointed to manage some government agencies. However, the discontentment continued and the opposition to the government was becoming stronger each day. The government's response was to issue a decree to forbid propagation of rumours. Additionally, a number of independent newspapers were banned, with some of their journalists being detained. While Ghanaians were calling for a return to democratic rule, Acheampong's response to the call was a union government. ${ }^{2}$ This was, however, opposed by the majority of Ghanaians, including university students, lawyers, and other organised civilian groups. While a national referendum was held in March 1978 to decide whether the country should adopt the union government concept, Acheampong was accused of twisting the votes to narrowly favour the union government (ibid). This deepened the public disaffection for the government and in July 1978, some officers of the SMC forced Acheampong to resign and replaced him with his second in command, Lieutenant General Frederick W. K. Akuffo.

While Lieutenant General Akuffo was preparing to usher Ghana into civilian constitutional rule, Flt-Lt Jerry Rawlings toppled his government on 4 June 1979. Interestingly, the new military government, which called itself the Armed Forces Revolutionary Council (AFRC), made sure the planned elections took place and Ghana returned to constitutional rule by the end of September 1979. However, after 27 months in office, the civilian government of the People's National Party (PNP) led by Dr Hilla Limann was toppled, once again by Rawlings and his colleagues, who thought the civilian government could not perform to expectations.

Upon assumption of executive powers on the eve of 31 December 1981, Rawlings established the Provisional National Defence Council (PNDC) and suspended the 1979 constitution, proscribing the existing political parties. The first year of PNDC rule witnessed a large dose of vigilante justice aiming to root out corruption and restore economic justice (Gyimah-Boadi and Jeffries, 2000). Yet, the inherited economic problems and severe drought during those years combined to adversely affect the welfare of Ghanaians. This led to an incessant number of unsuccessful coups. After failing to convince the Soviet Union to help Ghana out of the crises, Rawlings seemed to have shaken off his socialist stance and turned to the Bretton Wood Institutions for help (Kreav, 2004). There were no more easy pickings o,r indeed, other options.

The narration of the political history of this period points to the fact that immediately after the departure of Nkrumah from the political scene, heads of the military government that took over remained very powerful. While various attempts were made to return the country to constitutional rule, it did not happen until 1969.

\footnotetext{
${ }^{2}$ The Union government was a mixture of elected civilian and appointed military leaders. but without any party politics.
} 
Therefore, between the period 1966 and 1969, the political settlement that evolved was both personalised and uncompetitive. The top hierarchy of the military government rotated the leadership among a selected few, with limited opportunity for civilians to be at the very top of the decision-making process in the country. However, the political scene became competitive when Ghana briefly returned to constitutional rule during 1969-1971. This was short-lived, as the government was overthrown in 1972. There was further electoral competition in 1979, which was again shortlived, as the military took over in 1981.

For the majority of the 1970s, the political environment in Ghana was highly unstable and uncompetitive. Business owners, who were affiliated to Acheampong, the longest serving head of state during that era, saw their businesses blossom. Civil society, trade unions and students were unrelenting in their bid to fight for constitutional rule. Their effort appeared to have yielded some dividend when the country again returned briefly to constitutional rule (1979-1981). We would therefore argue that the political settlements over both phases, (1966-1974 and 1974-1983), were largely uncompetitive and personalised, except for the brief stints in 1969-1972 and 1979-1981, when the country completed elections.

\section{The deals environment (1966-1983)}

The ideological stance of a new civilian government that came to power following the 1966 military overthrow of Nkrumah, was pro private business. This government introduced reforms to liberalise the external sector, among others (see FrimpongAnsah, 1992). It is fair to say that the government at the time sought to make the deals space more open by liberalising not just trade, but also devaluing the exchange rate to reflect the market fundamentals. Unfortunately, it is this liberal stance that led to overthrow of the government in January 1972. The reforms of the government during this period, however, did not significantly affect relations among economic agents. The political space that had begun to open and become more competitive was shortlived. It is therefore fair to assert that even though the intent on making the deals space more open was there, it never materialised in practice over this period. Indeed as Killick (2010: 64) notes:

There remained much continuity after 1966; attempts to move towards greater use of the market mechanism were half-hearted and partial; and the soldiers who overthrew Busia in 1972 rapidly demonstrated a faith in a command economy similar to Nkrumah's, even though they displayed little interest in his socialism.

The 1972-1983 period was one of sustained deterioration in the economy under five different governments. Under the different, mostly military, governments, the policies of the period emphasised import substitution, underpinned by a restrictive foreign exchange regime, quantitative restrictions upon imports, and price controls, with the state playing a major role as producer. As a result, the political space was politically uncompetitive and highly personalised. Indeed, the capricious nature of the changes 
in government, coupled with the haphazard way in which policies were implemented, meant that not only did the deals space remain closed, it had become quite disordered by the end of this period. It is little wonder that Killick (2010: 398) describes this period as the "black years".

\section{Nature of politics and political settlements (1983-2001)}

In an attempt to solve the mounting economic problems confronting the country, the PNDC government proclaimed a structural adjustment reform package, popularly known as the Economic Recovery Programme (ERP), in 1983 (Kraev, 2004). These reforms were designed on the basis of the neo-liberal orthodoxy, with a particularly optimistic view about the efficacy of the market mechanism as a vehicle for the promotion of efficiency and development (Aryeetey and Tarp, 2000). It is further argued that not much attention was given to the fact that unbridled liberalisation of the markets can only be guaranteed to increase efficiency in a 'first best' world (ibid). The reality, however, was that there were many ill-functioning markets, such as that of insurance and credit. Additionally, the crowding out of the public sector by the private sector was seen as the critical ingredient and little attention went into exploring what was required to ensure the private sector would respond to incentives (Aryeetey and Tarp, 2000).

Even though the reforms occurred in the political context of a military dictatorship, they did manage to record some degree of success, which made Ghana appear as an icon of hope and a frontrunner in adjustment in the eyes of the international community. ${ }^{3}$ In the late 1980s, the government embarked on a series of democratisation reforms, culminating in the eventual reintroduction of multi-party democracy in the early 1990s (Kraev, 2004). While aid immediately started flowing to Ghana with the start of the economic recovery programme, the donors mounted pressure on the government to open up the political process (Whitfield, 2011). In response to this, the PNDC officially inaugurated the National Commission on Democracy $^{4}$ (NCD) in January 1985 , with the task of specifically studying ways to establish participatory democracy in Ghana. A few years later, the NCD recommended the formation of district assemblies as local governing institutions that would bring democracy to the doorstep of the ordinary person. Based on these recommendations, the government scheduled elections of the proposed assemblies in the last quarter of 1988 (McLaughlin and Owusu-Ansah, 1994: 5). The return to democratic rule became complete when general elections were held in the last quarter of 1992. Overall, Ghana enjoyed remarkable political stability throughout the period, with occasional protests, but no civil unrest and effective opposition to the economic reforms (Kraev, 2004).

\footnotetext{
${ }^{3}$ Domestically, government resorted to strong repressive measures to silence any opposition that harboured ill-feelings against the reforms (Kraev 2004: 5).

${ }^{4}$ The National Commission for Democracy (NCD) had existed as an agency of the PNDC
since 1982 .
} 
Not only did the Rawlings' National Democratic Congress (NDC) win the November 1992 presidential elections, but a subsequent boycott of the December Parliamentary elections by the New Patriotic Party (NPP) and the other opposition political parties gave way to the NDC-dominated first Parliament of the Fourth Republic. Rawlings held onto power, successfully serving two terms. Since the 1992 constitution does not allow a third term, he bowed out of political power after 19 years as the leader of the country.

After toppling the constitutionally elected government in 1981, Rawlings ruled for 11 years before returning the country to democracy. For the majority of this period, everything - cultural, social, political and economic - was built around him and his political cronies. The political settlement over this period was very personalised and uncompetitive.

Ghana returned to constitutional rule in 1992, with Rawlings still at the helm until January 2001. Even as democratically elected head of state, he remained very powerful. The constitution of Ghana enjoins the president to appoint the majority of his ministers from parliament. Therefore, the majority of the executive was also part of the legislature, a situation that has compromised the policing role of the legislature. It is little wonder that many argue that parliament has not been effective in its oversight responsibility on the executive.

\section{The deals environment (1983-2001)}

Ghana began with the structural adjustment programme in 1984. The SAP led to an economic liberalisation of various sectors of the economy. Exchange rate policy, fiscal and monetary policies, privatisation, and trade policies all saw dramatic changes. However, from the inception of the SAP in 1984 to 1992, political settlements in Ghana remained uncompetitive and highly personalised. The beginning of multiparty democracy in 1992 brought about a change in political settlements with a shift to political competitiveness albeit still remaining highly personalised. The deals environment during the 1984-2001 period became more ordered but largely closed especially for the dominant and high rent seeking sectors like mining and petroleum.

\section{Nature of politics and political settlements (2001-2014)}

The current economic and political dispensations have their roots in 1992 when the country adopted a constitutional rule. Rawlings contested and won the first two presidential elections on the ticket of the National Democratic Congress (NDC). John Agyekum Kufuor, who stood on the ticket of the opposition party, the New Patriotic Party (NPP), won the election, and became President on 7 January 2001. He was reelected in the 2004 presidential elections. The NPP government was deemed to be more business-friendly and initiated a number of programmes to promote private enterprise development in the country (Asem, Busse, Osei and Silberberger, 2013). The economic situation in the country attracted a number of foreign banks, while most local banks expanded their frontiers. Not only did the cost of credit become 
relatively lower, but for the first time in many years Ghana witnessed a situation where commercial banks were chasing customers to take loans. This era, often described as the golden age of business, saw a boom in the private sector. The economic growth rate was outstanding, with the economy growing at an annual average of 5.8 percent between 2001 and 2008.

After eight years of absence, The NDC won the 2008 general elections. The new President, Professor Evans John Atta Mills died in July 2012, before the end of his first term. His vice-president, John Dramani Mahama, took over and won the 2012 general election to become the substantive President of Ghana.

We argue that many years after Rawlings left power and even though elections have become highly competitive, the degree of political patronage and personalisation remains high. Public institutions remain weak and there is widespread perception of corruption. Even though Ghana's current political system is supposed to be multiparty, the results of the various presidential elections since 1992 indicate a de facto two-party system. The National Democratic Congress (NDC) has won four elections (in 1992, 2006, 2008 and 2012) with The New Patriotic Party (NPP) winning the remaining two (2000 and 2004). The NDC has overwhelmingly won in Volta, Northern, Upper West and Upper East regions in all the elections. The NPP has always been stronger in the Ashanti and Eastern regions, with the rest of the regions swinging mostly in favour of the NDC.

There is a winner-takes-all approach to governance, which is probably implicitly engendered by the constitution. This has also not helped to drive a business-friendly political settlement. The ruling government hardly shares power and works mostly to satisfy its supporters, whose perceived hard work had brought the party to power. Ghana is now polarised, with the dominant political parties (NDC and NPP) politicising almost all issues, as well as the civil and public service.

Another issue that appears to have made the state executives very powerful is the seemingly partisan control over law enforcement agencies by the ruling political party (Hassan, 2013). While monopoly of the government over the state media has not been in a doubt, the emergence of the private media in Ghana has, to some extent, eroded that monopoly. Aside from the good work the Ghanaian media is presently doing, sections of it appear to have been hijacked by the two dominant parties, who have successfully established a clientelistic control over some of the media houses. As a result, most of the economic and political issues that come to the attention of the public are often twisted by the media to suit the whims and caprices of their paymasters.

Even though the executive wields excessive powers, the country still displays a number of features of democratic institutionalisation that makes it a success story of democratic transformation in Africa (Oduro, Mohammed and Ashon, 2014). Figure 11 illustrates the key actors and groups and the levels of influence they exert in policy process in the country. Political elites, especially those in the ruling government, are the most powerful powerbrokers in Ghana. Groups such as traditional authorities, 
security agencies and bureaucrats are powerful and would always want the current arrangements of the political settlement to be maintained. Groups that are always pushing for change include the private media, trade unions, donors and the clergy (Hassan, 2013).

Figure 11. Distribution of key actors in the Ghana political settlement

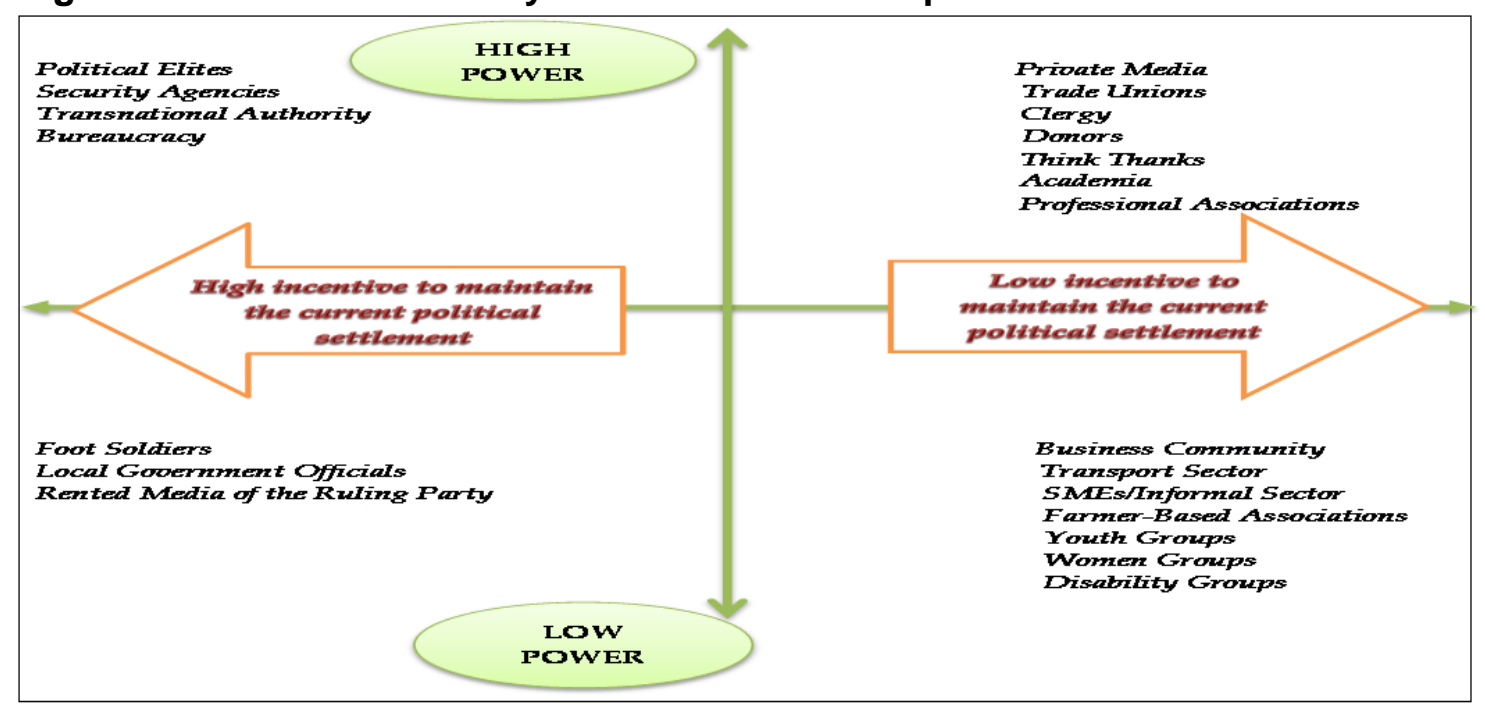

Source: Adapted from Hassan (2013).

One group whose influence on decision-making appears to be soaring is the foot soldiers, particularly of the ruling party of the day. In recent years, the executive has made certain decisions after public outcry by some members of this group. Less powerful groups that have been pushing for change, such as disability groups, have not had much of an influence on policy. Indeed, this characterisation of the key actors in policy making is very much consistent with findings of Asem et al. (2013). They argue that whilst donors have been influential in changing the regulatory environment in Ghana, the private sector has had less of an influence.

\section{The deals environment (2001-2012)}

The period of 2002 to date has probably seen the biggest attempted shift towards a more open and ordered deals space. Donors have largely driven these changes, particularly in the regulatory environment, with limited private sector influence on these changes (Asem et al. 2013). Unfortunately, the discovery and production of oil, coupled with the change in the country's status to middle income, has meant that the influence of donors is increasingly waning. We would argue that over the last decade the deals space remains closed, but less so relative to the earlier periods.

\section{The deals environment in Ghana today and implications for growth}

In this section we discuss the nature of the deals environment as reflected by selected businesses in Ghana today. Although the selection of the firms was nonrandom, it covers most of the typologies that were discussed under Figure 3 . The distribution of the firms interviewed and shown in Figure 12 is consistent with the general distribution of firms in Ghana. We note that most of the firms are workhorses 
with very few magicians and rentiers. In spite of the limited number of export-oriented firms, they tend to dominate the industrial landscape in Ghana (Sutton \& Kpentey, 2012). We therefore use results of the interviews from these broad categorisation of firms to discuss the contemporary deals space in Ghana. Based on our discussion on the "rents space" and the corresponding demands on the state, we expected the majority of these firms to favour a more open environment.

Figure 12. Distribution of firms interviewed by rents-space typology

\begin{tabular}{|c|c|c|}
\hline & High-rent & Competitive \\
\hline 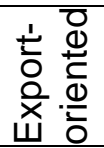 & $\begin{array}{c}\text { RENTIERS } \\
\text { Firms interviewed: Small scale } \\
\text { mining }\end{array}$ & $\begin{array}{l}\text { MAGICIANS } \\
\text { Firms interviewed: Pharmaceuticals } \\
\text { company }\end{array}$ \\
\hline & $\begin{array}{l}\text { POWERBROKERS } \\
\text { Firms interviewed: Commercial } \\
\text { bank, solar energy firm, medical } \\
\text { laboratory, saw mill, ICT }\end{array}$ & $\begin{array}{l}\text { WORKHORSES } \\
\text { Firms interviewed: Printing press, } \\
\text { furniture manufacturer, restaurant } \\
\text { operator, herbal medicine producer, } \\
\text { small-scale shoe producer, fast food } \\
\text { company, supermarket, auto repairs }\end{array}$ \\
\hline
\end{tabular}

Source: Authors construct based on typology in Figure 3.

\section{Importance of relationships and fairness for business growth in Ghana}

The view of almost all the businesses surveyed was that having good relationships with actors such as politicians, technocrats and union leaders is important for business growth. This view was generally held by firms in all the four categories outlined in Figure 12

. They further argued that whilst the relationship with the low- ranking bureaucrats and union leaders is fairly predictable and ordered, the relationship with high-ranking bureaucrats and politicians is less so.

There were differences of opinion with respect to whether the business playing field was level for all. In particular the rentiers argued that the playing field was not equal. They used access to capital to illustrate the point - arguing that whereas it is easy for any big firm to access capital (both in terms of ease and cost), the same could not be said of smaller firms. That view was also held by the magicians, who made the point that difficulty in accessing credit makes the implementation of new ideas relatively more difficult for smaller firms. This is consistent with our conceptual framework, where we argue that disordered and closed deals signal that commitments are not credible. For the firms that operate on the domestic market, even though they argued that the playing field is not fair, their focus and examples used were in relation to gaining contracts from the public sector. In their view, it is important always to have good relationships with key actors in society. This they claim is necessary for their business growth. Indeed, the interviews further revealed that making informal payments was necessary for business survival and growth. One of the key informants argued further that such payments are particularly rife in the highly regulated sectors of the economy. 
Generally we argue, based on these findings, that the deals environment remains closed in Ghana. The degree though varies by the type and size of enterprise. Additionally, we note that the factors that fuel the nature of the deals environment today are the fact that government remains a major procurer of goods and services, plus the cost of capital, which remains high. Some of the firms that operate as workhorses noted that they wish to become magicians, but that making the transition is difficult.

\section{Past and future of the business environment in Ghana}

Interestingly, we find that firms in the export sector generally argue that that the business environment has improved only marginally over the years. This is interesting, given the fact that studies have shown that firms in the export sector have generally performed better than non-exporting firms (see, for instance, Rankin, Söderbom and Teal, 2006). In our interviews the firms that operate domestically generally assert that the business environment has seen major improvements over the last 20 years. They base their argument on the fact that access to credit has improved, even though the cost still remains high. From these findings, we infer that, even though access and cost of credit seem to be a general constraint, the powerbrokers and the rentiers are able to overcome this constraint more easily than the magicians and, particularly, the workhorses.

In terms of the exporting firms, they argue that businesses can only grow if government implements strategic policies. Indeed, they make the point that the business environment needs to improve, citing the example of interest rates. Businesses in the domestic sector were more positive in terms of the future business environment.

\section{Constraints to business expansion}

Several factors hinder the rapid expansion of small-scale businesses in Ghana in recent times. Martey et al. (2013) find, for instance, that factors such as transportation costs, access and cost of credit constrain small business growth in Accra. Interviews carried out as part of this study indicate that one of the big challenges for business expansion in Ghana is the access to and cost of capital. The magicians and workhorses in our sample particularly echoed this. Interestingly, one of the things that the Rentiers also mentioned as being especially problematic was the capital outlay required for increasing investments. This suggests that Ghana still faces some bureaucratic constraints that manifest themselves in inadequate public goods and macroeconomic policies that can help cure these problems.

\section{Conclusions}

This study had a simple aim; to provide an assessment of the role that the nature of the political settlements have played in shaping the deals space and consequently economic growth in Ghana. It does this by first discussing the growth trajectory of Ghana in the four growth transition periods as identified in Karet al. (2013). The first 
growth transition is identified in 1966, which was positive (i.e. a significant increase in the growth) and coincides with Nkrumah's big push; the second in 1974, which was negative (i.e. a significant decrease in the growth) and coincides with a largely uncompetitive and personalised political settlements regime; the third in 1983, which was positive and coincides with the end of the 'black years' and the start of the structural adjustment programme; and the fourth in 2002, which was positive and coincides with improved state-business relations. We further discuss the political settlements as well as the deals environment in Ghana over these four periods. Finally, using interviews conducted with 21 enterprises and key informants, we discuss the nature of the deals space across the different types of enterprises as well as their prospects for growth. The main findings of this study can be summarised as follows.

First, we note that Ghana has seen sustained positive growth since the mid-1980s to date. The savings and investment trends also reflect the trends in GDP. However, much of the investment in the country has been financed from foreign aid and foreign private capital. Private capital investment has been highly skewed towards the natural resource sectors. We note further that growth has been associated with the changing contributions of the sectors. In particular, we note that the services sector has become more important relative to agriculture over the years, with the manufacturing sector remaining the same as it was at the start of independence. Also, labour from the declining agriculture sector has not necessarily moved to higher productivity wage employment in the services and manufacturing sectors. Rather, it has largely moved to equally low productivity activities in the services sector. We therefore argue that the changing structure has not been of the growth-enhancing type or transformative.

Second, we note that the country's exports continue to be dominated by a small number of products: mainly timber, gold, cocoa and, more recently, oil. This, we argue, has not helped to improve the fragility of the economy. We further argue that the structure of production, as captured by the economic complexity index, has not changed since 1960. This supports the earlier finding that in spite of the changes in the composition of output in Ghana, true structural transformation is yet to occur.

Third, the study argues that political settlements in Ghana have generally been highly personalised, even though there have been swings between competitive elections and a military or pseudo one party state. This, we argue, helps explain why growth maintenance has not been a regular feature of Ghana's growth. We note that the ruling governments have hardly shared power in Ghana in any true sense, with the country in recent times polarised around the two dominant political parties, the NDC and NPP. Also over the Nkrumah era to the end of the PNDC era, political settlements in Ghana were mostly personalised and uncompetitive. The only exception was the short period of 1969-1971 after Nkrumah's overthrow, when the military handed over power to a democratically elected government of Busia. Indeed, up to about 1992 these vampire elements (Frimpong-Ansah, 1992) remained and ensured that political settlements were highly personalised. From about 1992, even 
though there has been political competition, one can argue that they have remained personalised. It must be said that the increasing pressure of civil society, plus that from donors, is pushing the settlement towards a rule-governed one. There is, however, still some way to go for Ghana in spite of the strides it has made democratically.

Finally, we argue that the deals space has remained closed even though it varies for different firms depending on the 'rents space' in which they operate. The nature of the deals space in Ghana reflects a country that has not been able to move through the product space. This is also reflected in the earlier finding that the structure of production has not changed much for Ghana. In other words, Ghana has not been able to move to a more sophisticated area of product space, where goods and services produced embody more knowledge, command higher value, and provide greater returns from labour. There is no doubt that the closed nature of the deals space has influenced the fact that economic growth in Ghana over the years has not been of the transformative type. Indeed, had the deals environment in Ghana been more open, there is little doubt that it would have driven increased competition, which would have fuelled innovation and moved the country through the product space.

We conclude by noting that the deals space in Ghana is largely a product of the nature of the political settlement. It is also true that the political settlement feeds off the closed deals space. One could argue therefore that Ghana finds itself in an equilibrium that makes change to a deals space that fosters sustained accelerated growth difficult. Unfortunately for Ghana, declining foreign aid is accompanied by a declining major force for regulatory changes that would push the deals environment towards an open and ordered space. It is therefore imperative that civil society and, in particular, the growing middle class that has been relatively passive, double their efforts in pushing for a relatively more rule-based political settlement and, indeed, a more ordered and open deals space. 


\section{References}

Aryeetey, E. and Harrigan, J. (2000). 'Macroeconomic and structural developments since 1970'. In E. Aryeetey, J. Harrigan and M. Nissanke, Economic Reforms in Ghana: The Miracle and the Mirage (pp. 5-31). Oxford: James Curry Ltd.

Aryeetey, E. and Tarp, F. (2000). 'Structural adjustment and after: Which way forward? Economic reforms in Ghana'. Academy of Review, 12(1), 67-75.

Asem, F., Busse, M., Osei, R. and Silberberger, M. (2013). 'Private sector development and governance in Ghana'. The International Growth Centre Working Paper. London, UK: The International Growth Centre.

Boafo-Arthur, K. (2000). 'The political economy of Ghana foreign policy: Past, present and the future'. Ghana Social Science Journal, 1(1).

Darko, K. O. (2010). The Politics of Government Business Relations in Ghana, 19822008. New York: Palgrave Macmillan.

Di John, J. and Putzel, J. (2009). 'Political settlements: Issue paper'. Governance and Social Development Resource Centre.

Frimpong-Ansah, J. H. (1992). The Vampire State in Africa: The Political Economy of Decline in Ghana. London: James Curry Ltd.

Gollin, D., Jedwab, R. and Vollrath, D. (2013). 'Urbanization with and without structural transformation'. Mimeo. George Washington University.

Gyimah-Boadi, E. and Jeffries, R. (2000). 'The political economy of reform'. In E. Aryeetey, J. Harrigan and M. Nissanke, Economic Reforms in Ghana: The Miracle and the Mirage (pp. 32-50). Trenton, NJ: Africa World Press.

Hassan, M. (2013). 'Political settlement dynamics in a limited-access order: The case of Bangladesh'. ESID Working Paper 23. Manchester: Effective States and Inclusive Development Research Centre.

Hausmann, R., Pritchett, L. and Rodrik, D. (2005). 'Growth accelerations'. Journal of Economic Growth, 10(5), 303-329.

Hidalgo, C. A. and Hausmann, R. (2009). 'The building blocks of economic complexity'. Proceedings of the National Academy of Sciences, 106(26), 10570-10575.

Jedwab, R. and Osei, R. D. (2012). 'Structural change in Ghana, 1960-2012'. IIEP Working Paper. Washington, DC: George Washington University, Institute for International Economic Policy. 
Kar, S., Pritchett, L., Raihan, S. and Sen, K. (2013). 'Looking for a break: Identifying transitions in growth regimes'. Journal of Macroeconomics, 38, 151-166.

Kelsall, T. and Heng, S. (2014). 'The political settlement and economic growth in Cambodia'. ESID Working Paper 37. Manchester: Effective States and Inclusive Development Research Centre.

Killick, T. (2010). Development Economics in Action: A Study of Economic Policies in Ghana (2nd ed.). London: Routledge.

Killick, T. and Malik, M. (1992). 'Country experiences with IMF programmes in the 1980s'. The World Economy, 15(5), 599-632.

Kraev, E. (2004). 'Structural adjustment policies in Ghana in the 1990s: An empirical analysis and policy recommendations'. UNDP commissioned paper.

Martey, E., Annin, K., Attoh, C., Wiredu, A. N., Etwire, P. M. and Al-Hassan, R. M. (2013). 'Performance and constraints of small and medium enterprises in the Accra Metropolitan Area of Ghana. European Journal of Business and Management, 5(4), 83-93.

McLaughlin, J. and Owusu-Ansah, D. (1994). 'Historical setting'. In L. V. Berry, Ghana: A Country Study. Washington, DC: Federal Research Division, Library of Congress.

McMillan, M. S. and Rodrik, D. (2011). 'Globalization, structural change and productivity growth'. National Bureau of Economic Research (w17143).

Miller, F. P., Vandome, A. F. and McBrewster, J. (eds) (2009). History of Ghana. Mauritius: Alphascript Publishing.

Nohlen, D., Thibaut, B. and Krenn, M. (1999). Elections in Africa: A Data Handbook. Oxford: Oxford University Press.

Oduro, A. D. (2000). 'Performance of the external trade sector since 1970'. In E. Aryeetey, J. Harrigan and M. Nissanke, Economic Reforms in Ghana: The Miracle and the Mirage (pp. 185-208). Oxford: James Curry.

Oduro, F., Mohammed, A. and Ashon, M. A. (2014). 'A dynamic mapping of the political settlement in Ghana'. Centre for Democratic Development Working Paper Series .

Osei, R. D. (2012). 'Aid, growth and private capital flows to Ghana'. WIDER Working Paper (2012/22).

Osei, R., Morrissey, O. and Lloyd, T. (2005). 'The fiscal effects of aid in Ghana'. Journal of International Development, 17(8), 1037-1053. 
Pritchett, L. and Werker, E. (2012). 'Developing the guts of a GUT (Grand Unified Theory): Elite commitment and inclusive growth'. ESID Working Paper 16. Manchester: Effective States and Inclusive Development Research Centre.

Rankin, N., Söderbom, M. and Teal, F. (2006). 'Exporting from manufacturing firms in sub-Saharan Africa'. Journal of African Economies , 15 (4), 671-687.

Sen, K. (2013). 'The political dynamics of economic growth'. World Development , 47, 71-86.

Sen, K. (2012). 'The political dynamics of economic growth'. ESID Working Paper 5. Manchester: Effective States and Inclusive Development Research Centre.

Sen, K., Kar, S. and Sahu, J. P. (2014). 'The political economy of economic growth in India, 1993-2013'. ESID Working Paper 44. Manchester: Effective States and Inclusive Development Research Centre.

Sutton, J. and Kpentey, B. (2012). An Enterprise Map of Ghana. London: International Growth Centre.

Taylor, L. (1988). Varieties of Stabilization Experience: Towards Sensible Macroeconomics in the Third World. Oxford: Clarendon Press.

Teal, F. (1999). 'The Ghanaian manufacturing sector 1991-95: Firm growth, productivity and convergence'. The Journal of Development Studies, 36(1), 109-127.

Whitfield, L. (2011). 'Growth without economic transformation: Economic impacts of Ghana's political settlement'. DIIS Working Paper 2011: 28. 
Appendix 1. Export composition for Ghana, 1962

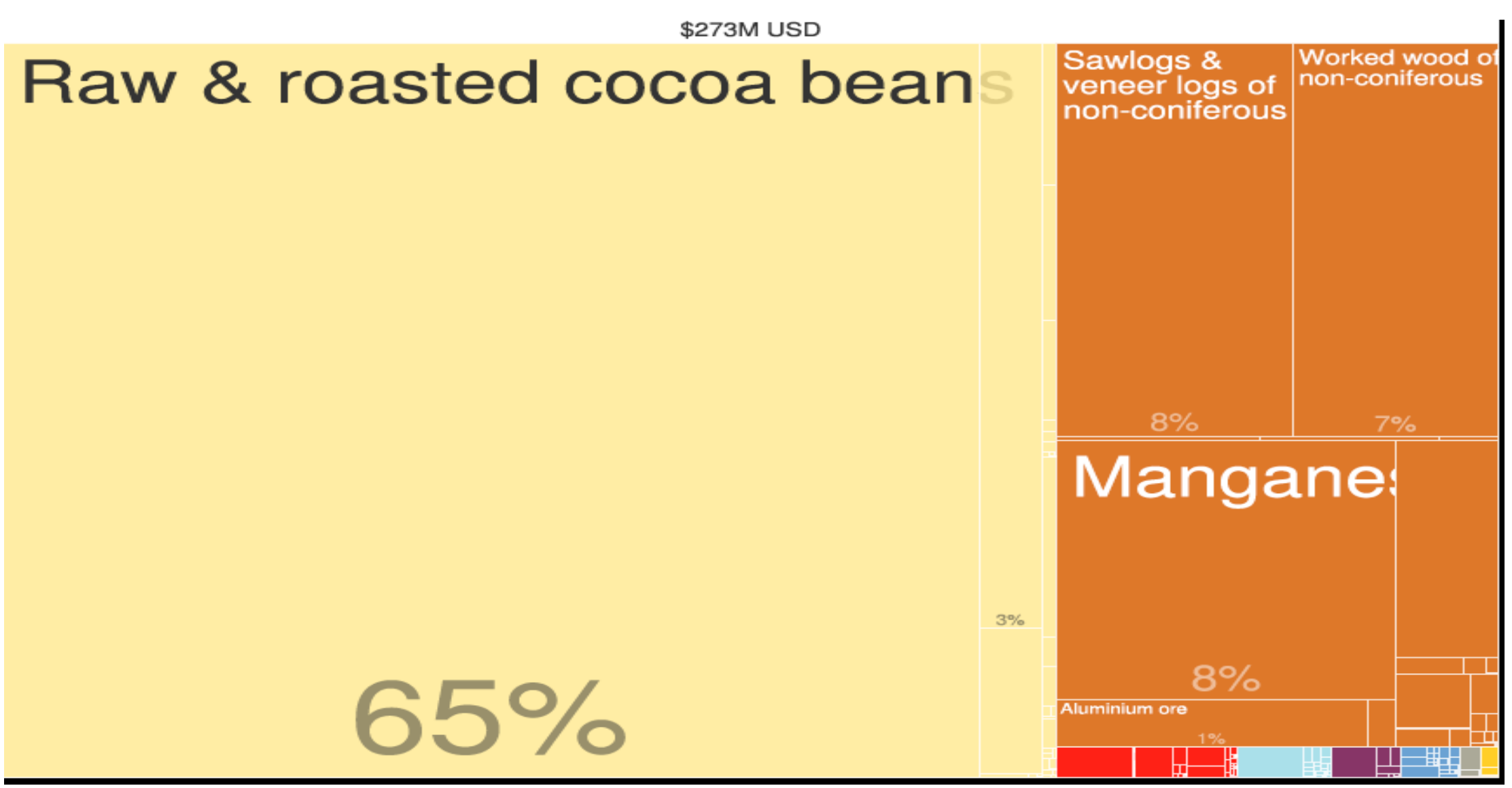

Source: Atlas of Economic Complexity, Version 1.0.7. 
Appendix 2. Export composition for Ghana, 1970

\$432M USD Raw \& roasted cocoa be

Sawlogs \& veneer

paste logs of non-coniferd

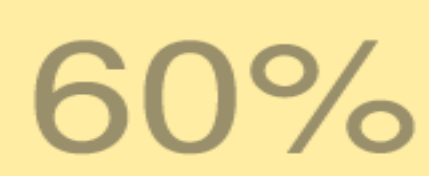

$7 \%$

Source: Atlas of Economic Complexity, Version 1.0.7. 
Appendix 3. Export composition for Ghana, 2000

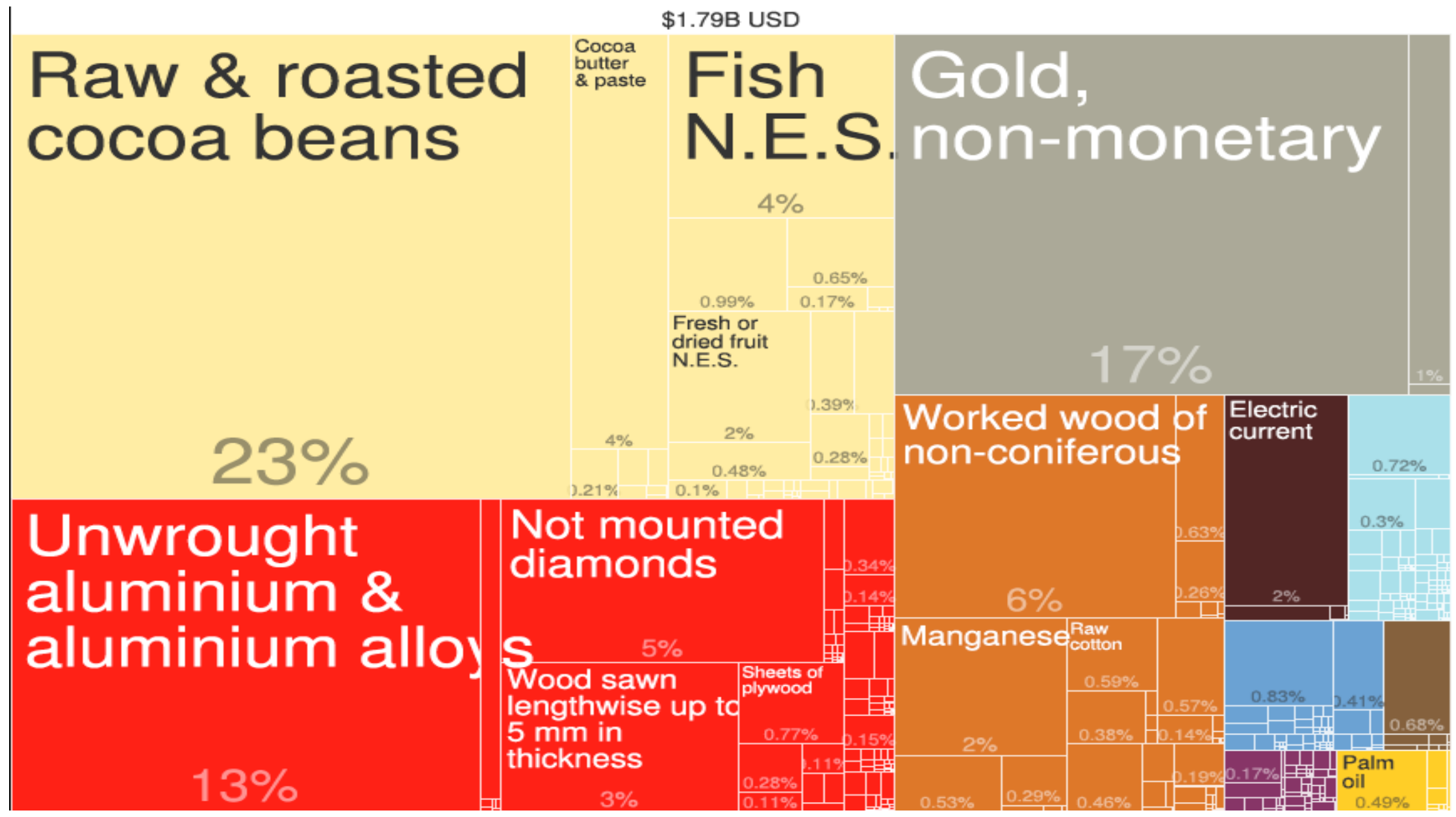

Source: Atlas of Economic Complexity, Version 1.0.7. 
Appendix 4. Export composition for Ghana, 2013

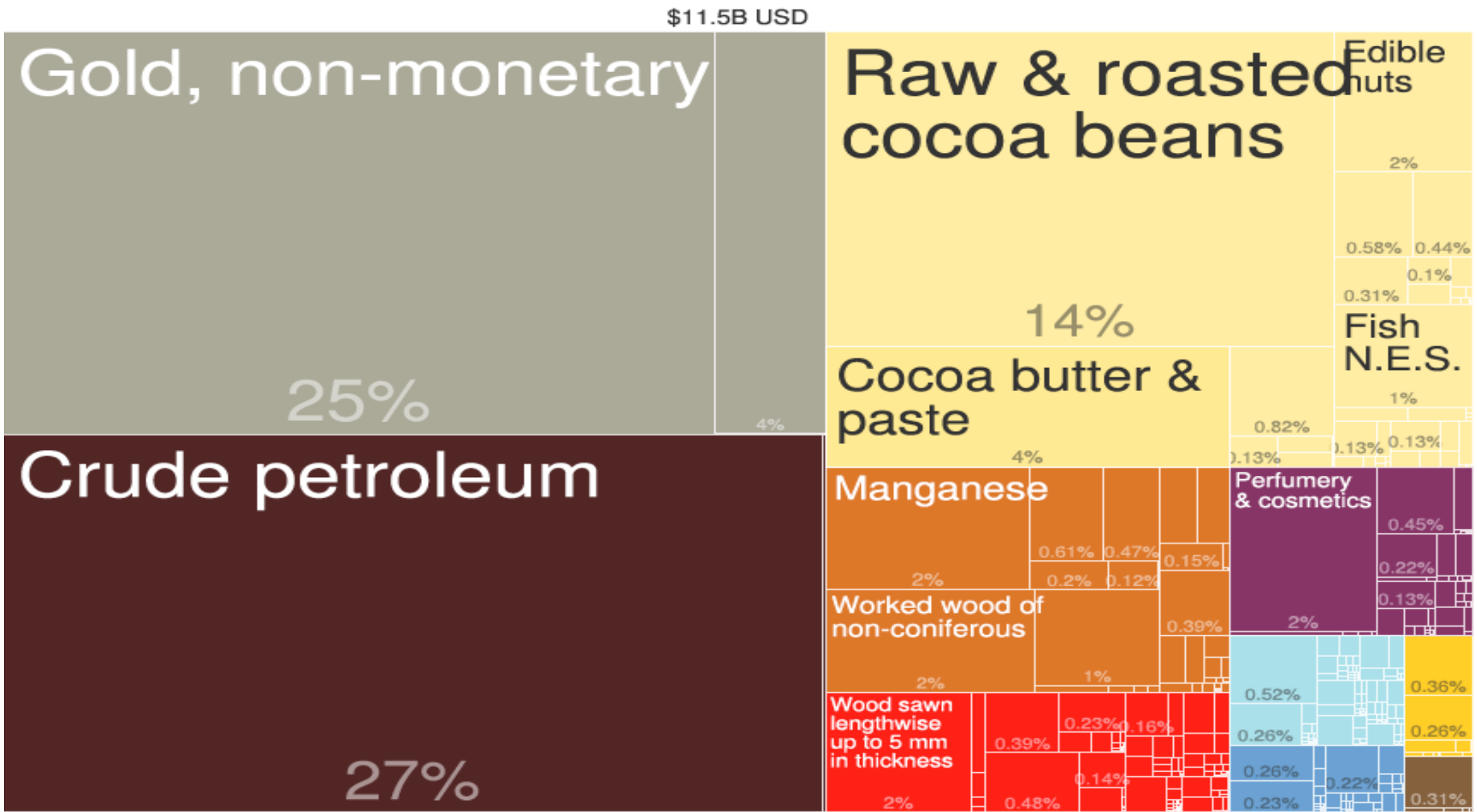

Source: Atlas of Economic Complexity, Version 1.0.7. 


\section{esid}

identifying routes to social justice

\section{The Effective States and Inclusive Development Research Centre}

The Effective States and Inclusive Development Research Centre (ESID) aims to improve the use of governance research evidence in decision-making. Our key focus is on the role of state effectiveness and elite commitment in achieving inclusive development and social justice.

ESID is a partnership of highly reputed research and policy institutes based in Africa, Asia, Europe and North America. The lead institution is the University of Manchester.

The other institutional partners are:

- $\quad$ BRAC Institute of Governance and Development, BRAC University, Dhaka

- $\quad$ Center for Democratic Development, Accra

- $\quad$ Center for International Development, Harvard University, Boston

- Department of Political and Administrative Studies, University of Malawi, Zomba

- $\quad$ Graduate School of Development, Policy \& Practice, Cape Town University

- Institute for Economic Growth, Delhi

In addition to its institutional partners, ESID has established a network of leading research collaborators and policy/uptake experts. 